\title{
Evaluation and characterization of Chilli (Capsicum annuum L.) germplasm for some morphological and yield characters
}

\author{
Waleed Quresh ${ }^{1,2}$, Mukhtar Alam ${ }^{1}$, Hidayat Ullah ${ }^{1 *}$, Shakeel Ahmad \\ Jatoi $^{2}$ and Wasif Ullah Khan ${ }^{3}$ \\ 1. Department of Agriculture, The University of Swabi, Khyber Pakhtunkhwa, Pakistan. \\ 2. Plant Genetic Resources Institute, National Agricultural Research Centre, Islamabad, Pakistan. \\ 3. Department of Plant Breeding \& Genetics, The University of Agriculture, Peshawar, Khyber Pakhtunkhwa, \\ Pakistan. \\ *Corresponding author's email: drhidayat@uoswabi.edu.pk
}

Citation

Waleed Quresh, Mukhtar Alam, Hidayat Ullah, Shakeel Ahmad Jatoi and Wasif Ullah Khan. Evaluation and characterization of Chilli (Capsicum annuиm L.) germplasm for some morphological and yield characters. Pure and Applied Biology. Vol. 4, Issue 4, 2015, pp 628-635. http://dx.doi.org/10.19045/bspab.2015.44023

Received: 26/08/2015 Revised: 06/11/2015

Accepted: 06/11/2015

\section{Abstract}

The study of genetic diversity and phenotypic variability in the available germplasm is a prelude to crop improvement. The present study was undertaken to characterize 10 accessions of Capsicum annuum acquired from the Centre for Genetic Resources, the Netherlands (CGN) through Plant Genetic Resources Institute (PGRI), National Agricultural Research Centre (NARC) Islamabad. The accessions were evaluated for 35 qualitative and 11 quantitative parameters. Wide variation was noted among the genotypes for important characters pertaining to fruit and seed yield. Such genetic variability can be a valuable resource for genetic improvement including developing resistance against insect pests and diseases. The available accessions need to be characterized in further detail under Pakistani agro-climatic conditions to ascertain the statistical significance of variability, understand the genetic control and gene interactions involved.

Key words: Capsicum annum L.; exotic germplasm; genetic variability; morphological differences.

\section{Introduction}

Pepper (Capsicum spp.) is one of the world's major vegetable and spice crop [1]. Globally, 1776 thousand ha land is estimated to be under cultivation of chillies producing around 7182 thousand tons. India is the largest producer of chillies in the world followed by China. Other important chilli producing countries include Pakistan, Ethiopia, Myanmar, Mexico, Vietnam, Peru,

Ghana and Bangladesh. Pakistan contributes around $6 \%$ to the world's total chilli production [2]. Chilli is the third important crop of the family Solanaceae after tomato and potato [3]. The genus Capsicum includes 30 known species [4]. The five most economically notable species of chillies are C. annuum, C. frutescens L., C. baccatum L., C. pubescens Ruiz. \& Pav., and C. chinense Jacq. [5]. Among the 
cultivated species the first two seems to have been domesticated in Mesoamerica while the later three species in South America [6, 7, 8]. The plant of chilli is usually bushy $60-80 \mathrm{~cm}$ high. It requires warm and humid climate for growth and dry weather during maturity. It is semi-perennial but usually cultivated as an annual [9].

Chilli pepper is thought to be the most popular spice with over $20 \%$ of the worlds' population using it in one or other form [10]. However in addition to culinary use (as spice, cooked vegetable, food ingredient, colorant etc.), Capsicum species are also used in cosmetics [4] and medicine [11]. Capsicum spp. contain a range of essential nutrients and bioactive compounds which are known to exhibit antioxidant, antimicrobial, antiviral, anti-inflammatory and anticancer properties [12]. Some of the known chemicals contained in Capsicum fruit include steam-volatile oils, fatty oils, capsaicinoids, carotenoids, vitamins, proteins, fiber and mineral elements [4]. Capsicums are an excellent source of Vitamins A, B, C, E and P. Fresh green chilli peppers contain more vitamin $\mathrm{C}$ than citrus fruits and fresh red chili has more vitamin A than carrots $[13,14]$.

Chilli is also an important cash crop of summer season in Pakistan, especially in Sindh and southern Punjab [9]. According to the Economic Survey of Pakistan [15] chilli crop was cultivated on a total area of 62700 hectares in 2013-14 with an annual production of 145800 tons. However, there has been a significant decline in the area under cultivation and production of chillies in Pakistan mainly because of the pests and pathogens, which cause considerable losses every year. Major insects, which attack on chilli plants, are aphids, mites, thrips etc. Among the fungal diseases, damping off, Phytophthora root rot, powdery mildew, Fusarium wilt, Anthracnose etc., are the most destructive [9]. Higher yield and host plant resistance genes have to be identified in the gene pool existing as land-races, wild and semi-domesticated relatives of cultivated species for exploitation in breeding programmes [16, 17]. The characterization and evaluation of accessions maintained in gene banks are of fundamental importance in this regard [11]. Since the study of genetic diversity and phenotypic variability in the available germplasm is a prelude to potential chilli crop improvement [18], therefore the present study was undertaken to characterize the available germplasm for use in breeding programmes.

\section{Materials and methods}

Characterization of 10 accessions of exotic nature was carried out at Plant Genetic Resources Institute (PGRI), National Agricultural Research Centre (NARC) Islamabad as part of a long-term project to characterize the $C$. annuum L. germplasm acquired from the Centre of Genetic Resources, the Netherlands (CGN) through the PGRI. Plants were grown in rows kept $75 \mathrm{~cm}$ apart. Plant-to-plant distance was kept $50 \mathrm{~cm}$. Usual agronomic and plant protection practices were adopted to grow the plants in the experimental field of NARC in the year 2014.

The germplasm comprised of 10 accessions of $C$. annuum viz. 'CGN-21462', 'CGN 17150', 'CGN-16828', 'CGN-1624', 'CGN16936', 'CGN-17014', 'CGN-17210', 'CGN-19178', 'CGN-19189' and 'CGN17212'. The germplasm was evaluated for 46 parameters that included qualitative (35) as well as quantitative (11). Qualitative traits were selected from plant descriptors developed by the IPGRI for Capsicum spp. [19]. The quantitative traits (listed in Table 1) were studied according to the standard procedure of recording data in chilli crop. Mean values were used for comparison. 
Table 1. Quantitative characters studied.

\begin{tabular}{|c|c|c|c|}
\hline S. No. & Character & Units & Remarks \\
\hline 1 & $\begin{array}{l}\text { Plant } \\
\text { height }\end{array}$ & $\mathrm{cm}$ & $\begin{array}{l}\text { Measured from ground level (base) to tip of the plant for } 10 \text { plants } \\
\text { each with the help of a measuring tape }\end{array}$ \\
\hline 2 & Leaf length & $\mathrm{cm}$ & $\begin{array}{l}10 \text { mature leaves each from } 05 \text { randomly selected plants at mid level } \\
\text { of the plant were measured from tip to petiole. The character is a } \\
\text { good indicator to judge photosynthesis and general health of the } \\
\text { plant with important bearing on yield. }\end{array}$ \\
\hline 3 & Leaf width & $\mathrm{cm}$ & $\begin{array}{l}10 \text { mature leaves each from } 05 \text { randomly selected plants were } \\
\text { measured at the broadest point from middle of the plant. }\end{array}$ \\
\hline 4 & Fruit length & $\mathrm{cm}$ & $\begin{array}{l}10 \text { fruits each from } 05 \text { randomly selected plants were measured. } \\
\text { Fruit length attracts customers and contributes to yield. }\end{array}$ \\
\hline 5 & Fruit width & $\mathrm{cm}$ & $\begin{array}{l}\text { Width of } 10 \text { fruits each from } 05 \text { randomly selected plants was } \\
\text { measured using Vernier calliper. Fruit width attracts customers and } \\
\text { contributes to yield. }\end{array}$ \\
\hline 6 & $\begin{array}{l}\text { Fruit } \\
\text { weight }\end{array}$ & $\mathrm{g}$ & $\begin{array}{l}\text { Weight of } 10 \text { individual fruits each from } 05 \text { randomly selected } \\
\text { plants was measured using electronic balance. Fruit weight attracts } \\
\text { customers and contributes to yield. }\end{array}$ \\
\hline 7 & $\begin{array}{l}\text { Fruit } \\
\text { pedicel } \\
\text { length }\end{array}$ & $\mathrm{cm}$ & $\begin{array}{l}\text { Length of } 10 \text { flowers each from } 05 \text { randomly selected plants was } \\
\text { measured using a scale. Long pedicel may expose the fruit to } \\
\text { sunlight. }\end{array}$ \\
\hline 8 & $\begin{array}{l}\text { Fruit wall } \\
\text { thickness }\end{array}$ & $\mathrm{mm}$ & $\begin{array}{l}\text { Thickness of fruit wall of } 10 \text { fruits each from } 05 \text { randomly selected } \\
\text { plants was measured using Vernier caliper. Thickness of fruit wall } \\
\text { can be important with regards to attack of insect pests on the fruit. }\end{array}$ \\
\hline 9 & $\begin{array}{l}\text { No of } \\
\text { locules }\end{array}$ & $\begin{array}{l}\text { Num } \\
\text { bers }\end{array}$ & $\begin{array}{l}\text { Number of locules was counted in } 10 \text { fruits each from } 5 \text { randomly } \\
\text { selected plants. }\end{array}$ \\
\hline 10 & $\begin{array}{l}\text { Seed } \\
\text { diameter }\end{array}$ & $\mathrm{cm}$ & $\begin{array}{l}\text { Seed diameter of } 10 \text { seeds each from } 5 \text { randomly selected plants was } \\
\text { measured using Vernier caliper. Seed diameter a useful indicator of } \\
\text { viability of the seed. }\end{array}$ \\
\hline 11 & $\begin{array}{l}\text { No of seeds } \\
\text { per fruit }\end{array}$ & $\begin{array}{l}\text { Num } \\
\text { bers }\end{array}$ & $\begin{array}{l}\text { Seeds were counted from } 10 \text { fruits each of } 5 \text { randomly selected } \\
\text { plants. Number of seeds in fruits indicates the success of pollination } \\
\text { and fertilization. }\end{array}$ \\
\hline
\end{tabular}

Results and Discussion

The current paper reports the preliminary evaluation of $C$. annuum germplasm, which were originally obtained from the Centre of Genetic Resources, the Netherlands (CGN); has collection of diverse Capsicum species [20]. The materials were evaluated for 35 qualitative descriptors selected from those developed by IPGRI [19] and also previously used by [21] and [8]. The results show that with regards to the following qualitative characters all the accessions were found to be similar (Table 2(a)).

However, the genotypes exhibited variation with respect to the following qualitative traits (Table 2(b)). 
Table 2 (a). Qualitative characters which were similar in all accessions.

\begin{tabular}{|l|l|l|l|l|l|}
\hline No & Character & Phenotype & No & Character & Phenotype \\
\hline a & Life cycles & Annual & f & $\begin{array}{l}\text { Anthocyanin spots on } \\
\text { corolla }\end{array}$ & Present \\
\hline b & Stems & Green & g & Neck at the base of fruit & Absent \\
\hline c & Nodal anthocyanin & Green & h & Ripe Fruit persistence & Slight \\
\hline d & Calyx pigmentation & Present & i & $\begin{array}{l}\text { Fruit appendage at } \\
\text { blossom: }\end{array}$ & Absent \\
\hline e & $\begin{array}{l}\text { Calyx } \\
\text { pigmentation annular }\end{array}$ & Present & j & Pedicel with stem & Persistent \\
\hline
\end{tabular}

Table 2 (b). Qualitative characters which were found to be variable.

\begin{tabular}{|l|l|l|}
\hline S. No. & Character & Phenotypic expression \\
\hline 1 & Stem shape & Angular or cylindrical \\
\hline 2 & Stem pubescence: & Intermediate or dense \\
\hline 3 & Plant growth habit & Prostrate or erect \\
\hline 4 & Tillering & Sparse, intermediate or dense \\
\hline 5 & Branching habit & Prostrate, intermediate and dense \\
\hline 6 & Leaf density & Intermediate, dense \\
\hline 7 & Leaf colour & Light green, green, dark green \\
\hline 8 & Leaf shape: & Ovate, lanceolate \\
\hline 9 & Lamina margin & Ciliate, intermediate, entire, undulate \\
\hline 10 & Leaf pubescence & Intermediate, dense \\
\hline 11 & Flower position & Pendant, intermediate, erect \\
\hline 12 & Corolla colour & White, light green, green \\
\hline 13 & Corolla spot colour & Green, yellow green \\
\hline 14 & Calyx margin & Entire, intermediate, dentate \\
\hline 15 & Fruit colour (intermediate stage) & Dark purple, yellow, light red, dark red \\
\hline 16 & Fruit colour (at maturity): & Purple, dark red \\
\hline 17 & Fruit shape & Cordated, blocky, elongated \\
\hline 18 & Fruit shape at pedicel attachment & Cordated, truncated, obtuse \\
\hline 19 & Fruit shape at blossom & Sunken, pointed, sunken and pointed \\
\hline 20 & Fruit cross sectional corrugation & Slightly corrugated, corrugated and intermediate \\
\hline 21 & Fruit surface & Smooth, wrinkle \\
\hline 22 & Pedicel with fruit & Persistent, intermediate \\
\hline 23 & Seed colour & Brown Light brown \\
\hline 24 & Seed surface & Rough, smooth \\
\hline 25 & Seed size & Small, intermediate and large \\
\hline & & \\
\hline
\end{tabular}


The genotypes were also evaluated for 11 quantitative traits as presented in Table 3 . It can be seen from the table that wide variation existed among the genotypes with regard to the traits studied. For example plant height ranged from $33.9 \mathrm{~cm}$ ('CGN21462 ') to $64.5 \mathrm{~cm}$ ('CGN-17150'), mean fruit weight ranged from $1.4 \mathrm{~g}$ (' $\mathrm{CGN}$ 19212 ') to $57.3 \mathrm{~g}$ ('CGN-17210'). Similar range of variability was observed for all the quantitative characters evaluated. It can be seen from the table that accession no. 'CGN17014' performed poorest for important characters that contribute to fruit yield (leaf length, leaf width) or seed yield (number of locules, no. of seeds per fruit). On the other hand accession no. 'CGN-17150' (plant height, fruit width) and 'CGN-17210' (leaf length, fruit weight) showed maximum values for important characters having a bearing on fruit yield [22].

Table 3. Mean max and min values for different characters among the $\mathbf{1 0}$ accessions

\begin{tabular}{|l|l|l|l|l|}
\hline Character & Min. value & Genotype & Max. value & Genotype \\
\hline 1. Plant height & $33.9 \mathrm{~cm}$ & 'CGN-21462' & $64.5 \mathrm{~cm}$ & 'CGN-17150' \\
\hline 2. Leaf length & $3.7 \mathrm{~cm}$ & 'CGN-17014' & $10.5 \mathrm{~cm}$ & 'CGN-17210' \\
\hline 3. Leaf width & $1.5 \mathrm{~cm}$ & 'CGN-17014' & $6.4 \mathrm{~cm}$ & 'CGN-19189' \\
\hline 4. Fruit length & $4.0 \mathrm{~cm}$ & 'CGN-19178' & $10.9 \mathrm{~cm}$ & 'CGN-21462' \\
\hline 5. Fruit width & $1.0 \mathrm{~cm}$ & 'CGN-19212' & $6.1 \mathrm{~cm}$ & 'CGN-17150' \\
\hline 6. Fruit weight & $1.4 \mathrm{~g}$ & 'CGN-19212' & $57.3 \mathrm{~g}$ & 'CGN-17210' \\
\hline 7. Pedicel length & $1.3 \mathrm{~cm}$ & 'CGN-19212' & $2.5 \mathrm{~cm}$ & 'CGN-17210' \\
& & 'CGN-19189' & & 'CGN-16936' \\
\hline 8. Fruit wall thickness & $0.7 \mathrm{~mm}$ & 'CGN-19212' & $5.1 \mathrm{~mm}$ & 'CGN-19189' \\
\hline 9. No. of locules & 2.0 & 'CGN-17014' & 4.3 & 'CGN-16924' \\
\hline 10. Seed diameter & $0.5 \mathrm{~cm}$ & 'CGN-16828' & $1.2 \mathrm{~cm}$ & 'CGN-21462' \\
\hline 11. No. of seeds per fruit & 31.7 & 'CGN-17014' & 243.3 & 'CGN-21462' \\
\hline
\end{tabular}

The high diversity in collection shows a great potential for improvement of agronomic traits in pepper [8]. High heritability for characters like fruit yield, fruit weight, fruits per plant, number of branches per plant, fruit diameter, pericarp thickness, pedicel diameter etc has been reported by previous workers such as [23, 24, 25].

The wide variation in the present investigation is supported by previous workers. Wide range of variability for a number of characters had been reported [26]. They had also noted positive correlation among certain characters which can be important for genetic improvement for example plant height has been reported to have a positive correlation with pedicle length [26]. Wide variation has also been reported among chilli genotypes by $[8,23$, $26,27]$. Some of the characters have been reported to be responsive to direct selection like fresh fruit weight, fruits per plant etc [23].

It is concluded that the accessions available in gene bank of PGRI possess wide variation for important characters as they have been obtained from different local and exotic origins. Moreover, the germplasm acquired from the CGN has shown potential variation. Such genetic variability can be a valuable resource for genetic improvement [17]. The available accessions need to be characterized in detail under Pakistani agro- 
climatic conditions to ascertain the statistical significance of variability, understand the genetic control and associations involved. In addition to other valuable characters contributing to yield, genetic resistance to diseases and pests can be the primary weapon to save the colossal losses in yield of chillies [28] which can also be useful in Pakistan where the area and production has seen significant decline due to insect pest and disease attacks [12]. Characterization of germplasm, especially that already available in gene banks can unearth genetic sources of resistance to insect pests and diseases [11].

Table. 4. Mean values recorded for 11 quantitative characters.

\begin{tabular}{|l|l|l|l|l|l|l|l|l|l|l|l|}
\hline Genotype & $\begin{array}{l}\text { Pl. Ht. } \\
(\mathbf{c m})\end{array}$ & $\begin{array}{l}\text { Lf. L } \\
(\mathbf{c m})\end{array}$ & $\begin{array}{l}\text { Lf. Wd } \\
(\mathbf{c m})\end{array}$ & $\begin{array}{l}\mathbf{F . L} \\
(\mathbf{c m})\end{array}$ & $\begin{array}{l}\text { F. Wd } \\
(\mathbf{c m})\end{array}$ & $\begin{array}{l}\text { F. Wt. } \\
(\mathbf{g})\end{array}$ & $\begin{array}{l}\text { P.L } \\
(\mathbf{c m})\end{array}$ & $\begin{array}{l}\text { W. T } \\
(\mathbf{m m})\end{array}$ & $\begin{array}{l}\text { Lc } \\
(\mathbf{N o s})\end{array}$ & $\begin{array}{l}\text { S. Dia } \\
(\mathbf{m m})\end{array}$ & $\begin{array}{l}\text { S/F } \\
(\mathbf{N o s})\end{array}$ \\
\hline 'CGN-21462' & 33.9 & 9.7 & 4.8 & 10.9 & 3.7 & 43.1 & 2.4 & 2.5 & 3.0 & 1.0 & 243.3 \\
\hline 'CGN-17150' & 64.5 & 5.7 & 3.3 & 8.1 & 6.1 & 5.8 & 2.3 & 3.6 & 3.7 & 0.5 & 112.0 \\
\hline 'CGN-16828' & 42.7 & 6.2 & 5.9 & 4.3 & 5.2 & 28.8 & 2.0 & 2.3 & 3.0 & 0.9 & 56.3 \\
\hline 'CGN-16924' & 38.1 & 7.0 & 3.7 & 5.4 & 4.7 & 47.3 & 2.0 & 3.5 & 4.3 & 0.9 & 107.7 \\
\hline 'CGN-16936' & 42.9 & 8.3 & 3.8 & 6.9 & 1.9 & 14.8 & 2.5 & 2.9 & 3.0 & 0.8 & 95.0 \\
\hline 'CGN-17014' & 58.4 & 3.7 & 1.5 & 4.4 & 4.2 & 2.8 & 1.8 & 0.8 & 2.0 & 0.7 & 31.7 \\
\hline 'CGN-17210' & 54.4 & 10.5 & 5.5 & 8.6 & 4.3 & 57.3 & 2.5 & 3.7 & 3.3 & 1.0 & 119.0 \\
\hline 'CGN-19178' & 39.8 & 9.2 & 5.2 & 4.0 & 5.4 & 49.3 & 2.1 & 3.9 & 4.0 & 0.9 & 62.7 \\
\hline 'CGN-19189' & 59.1 & 10.2 & 6.4 & 5.0 & 5.1 & 39.2 & 1.3 & 5.1 & 3.0 & 0.9 & 55.0 \\
\hline 'CGN-19212' & 42.3 & 4.8 & 2.8 & 4.1 & 1.0 & 1.4 & 1.3 & 0.7 & 2.3 & 1.2 & 37.3 \\
\hline
\end{tabular}

(PI. Ht = Plant Height, Lf. L= Leaf Length, Lf. Wd = Leaf Width, F.L = Fruit Length, F. Wd = Fruit Width, F. Wt $=$ Fruit Weight, $\mathbf{P} . \mathbf{L}=$ Pedicel Length, $\mathbf{W} . \mathbf{T}=$ Fruit Wall Thickness, $\mathbf{L} \mathbf{c}=$ No. of Locules, S. $\mathbf{D i a}=$ Seed Diameter, $\mathbf{S} / \mathbf{F}=$ Seeds per Fruit $)$.

\section{Authors' contributions}

Conceived and designed the experiments: W Quresh \& SA Jatoi. Performed the experiments: W Quresh. Analyzed the data: M Alam, H Ullah. Contributed reagents/materials/analysis tools: W Khan. Wrote the paper: H Ullah, M Alam.

\section{References}

1. Zewdie $\mathrm{T}$, Tong NK \& Bosland PW. (2004). Establishing core collection of Capsicum using a cluster analysis with enlightened selection of accessions. Genet Resour Crop Evol 51: 147-151.

2. Khan HA, Ziaf K, Amjad M \& Iqbal Q. (2012). Exogenous application of polyamines improves germination and early seedling growth of hot pepper. Chilean J of Agricultural Res 72(3): 429-433.
3. Naz S, Anjum MA \& Ahmad I. (2006). Growth of Chilli (Capsicum annuum L.) $\mathrm{F}_{1}$ hybrid sky line-2 in response to different ages of transplants. J Res (Sci) 17: 91-95.

4. Bosland PW \& Votava EJ. (2003). In Peppers: Vegetable and spice Capsicums. CAB International Publishing, Wallingford, England, UK: Pp- 204, Pp. 233.

5. Perry L, R Dickau, S Zarillo, I Holst, DM Pearsall, DR Piperno \& Berman MJ. (2007). Starch fossils and the domestication and dispersal of Chilli Peppers (Capsicum spp.) in the Americas. Science 315: 986-988.

6. Pickersgill B. (2007). Domestication of Plants in the Americas: Insights from Mendelian and Molecular Genetics. Annals of Bot 100: 925-940. 
7. Kraft $\mathrm{KH}, \mathrm{CH}$ Brown, GP Nabhan, E Luedeling, JD Luna Ruiz, GC D'Eeckenbrugge, RJ Hijmans \& Geptsa P. (2014). Multiple lines of evidence for the origin of domesticated chilli pepper, Capsicum annuum, in Mexico. Proc Natl Acad Sci USA. 111(17): 61656170.

8. Bozokalfa MK, D Esiyok \& Turhan K. (2009). Patterns of phenotypic variation in a germplasm collection of pepper (Capsicum annuum L.) from Turkey. Spanish J of Agricultural Res 7(1): 83-95.

9. Hussain F \& Abid M. (2011). Pest and diseases of Chilli crop in Pakistan: A review Int J Biol Biotech 8(2): 325-332.

10. Anwarul ASM \& Arshad FM. (2010). Technical Efficiency of Chilli production. Amer J Appl Sci 7(2): 185190.

11. Lahbib K, F Bnejdi \& El-Gazzah M. (2015). Selection of Pepper parent from a collection of Capsicum annuum landraces based on genetic diversity. JPBCS 5(5): 68-72.

12. Khan MA, MA Asghar, J Iqbal, A Ahmed \& Shamsuddin ZA. (2014). Aflatoxins contamination and prevention in red chillies (Capsicum annuum L.) in Pakistan. Food Additives \& Contaminants: Part B 7(1): 1-6.

13. Osuna-García JA, MW Wall \& Waddell CA. (1998). Endogenous levels of tocopherols and ascorbic acid during fruits ripening of New Mexican-type Chilli (Capsicum annuum L.) cultivars. Journal of Agricultural and Food Chemistry 46(12): 5093-5096.

14. Marin A, F Ferreres, FA Tomás Barberán \& Gil M. (2004). Characterization and quantization of antioxidant constituents of sweet pepper (Capsicum annuum L.). $J$ of Agricultural and Food Chemistry 52(12): 3861- 3869.
15. Anonymous. (2014). Pakistan Bureau of Statistics. Maize: area, production and yield. Agricultural Statistics of Pakistan, 2013-14. Federal Bureau of Statistics, Statistics Division, Islamabad, Pakistan. 1-273.

16. Sharma HC \& Ortiz R. (2002). Host plant resistance to insects: an ecofriendly approach for pest management and environment conservation. J Env Biol 23: 111-135.

17. Geleta LF, MT Labuschange \& Viljoen CD. (2005). Genetic variability in pepper (Capsicum annuum L.) estimated by morphological data and amplified fragment length polymorphism markers. Biodivers Conserv 14: 2361-2375.

18. Thul ST, RK Lal, AK Shasany, MP Darokar, AK Gupta, MM Gupta, RK Verma \& Khanuja SPS. (2009). Estimation of phenotypic divergence in a collection of Capsicum species for yield-related traits. Euphytica 168(2): 189-196.

19. IPGRI, AVRDC and CATIE. (1995). Descriptors for Capsicum (Capsicum spp.). International Plant Genetic Resources Institute, Rome, Italy; the Asian Vegetable Research and Development Center, Taipei, Taiwan, and the Centro Agronómico Tropical de Investigación y Enseñanza, Turrialba, Costa Rica. ISBN 92-9043-216-0

20. Aguilar-Meléndez A, PL Morrell, ML Roose \& Kim SC. (2009). Genetic diversity and structure in semiwild and domesticated chiles (Capsicum annuиm; Solanaceae) from Mexico. American Journal of Botany 96(6), 1190-1202.

21. Sudré CP, LSA Gonçalves, R Rodrigues, AD Amaral Júnior, EM Riva-Souza \& Bento CDS. (2010). Genetic variability in domesticated Capsicum spp. as assessed by morphological and agronomic data in 
mixed statistical analysis. Genetics and Molecular Research 9(1): 283-294.

22. Tembhurne BV \& Kuchanur PH. (2010). Varietal performance, genetic variability and correlation studies in Chilli (Capsicum annuum L.). Karnataka Journal of Agricultural Sciences 21(4): 541-543.

23. Karad SR, PA Navale \& Kadam DE. (2006). Variability and path-coefficient analysis in Chilli (Capsicum anпuиm L.). Int J Agric Sci 2(1): 90-92.

24. Ben-Chaim A \& Paran I. (2000). Genetic analysis of quantitative traits in pepper (Capsicum annuum). Journal of the American Society for Horticultural Science 125(1): 66-70.

25. Varalakshmi B \& Babu KH. (1991). Genetic divergence, heritability and genetic advance in Chilli (Capsicum annuum L.). The Indian Journal of Genetics and Plant Breeding 51(2): 174-178.
26. Joshi VC, VK Yadav, B Makanur \& Prasad B. (2013). Studies on growth parameters and seed quality in Capsicum (Capsicum annuum L.). BIOINFOLET-A Quarterly $J$ of Life Sciences 10(3a): 865-871.

26. Manju PR \& Sreelathakumary I. (2002). Genetic variability, heritability and genetic advance in hot Chilli (Capsicum chinense Jacq.). J Trop Agric 40: 4-6.

27. Sreelathakumary I \& Rajamony L. (2004). Variability, heritability and genetic advance in Chilli (Capsicum annuит L.). J Trop Agric 42: 35-37.

28. Ballina-Gómez H, L LatournerieMoreno, E Ruiz-Sánchez, A PérezGutiérrez \& Rosado-Lugo G. (2013). Morphological characterization of Capsicum annuиm L. accessions from southern Mexico and their response to the Bemisia tabaci-Begomovirus complex. Chilean $j$ of agricultural research 73(4): 329-338. 